\title{
EXPERIMENTAL SELVES
}

Person and Experience in Early Modern Europe 
This page intentionally left blank 
CHRISTOPHER BRAIDER

\section{Experimental Selves}

Person and Experience in Early Modern Europe 
(C) University of Toronto Press 2018

Toronto Buffalo London

utorontopress.com

Printed in the U.S.A.

ISBN 978-1-4875-0368-0

Printed on acid-free, $100 \%$ post-consumer recycled paper with vegetable-based inks.

\section{Library and Archives Canada Cataloguing in Publication}

Braider, Christopher, 1950-, author

Experimental selves : person and experience in early modern Europe /

Christopher Braider.

Includes bibliographical references and index.

ISBN 978-1-4875-0368-0 (hardcover)

1. Self in literature. 2. Self-perception in art. 3. Self-knowledge, Theory of History. 4. Self (Philosophy) - History. 5. European literature - History and criticism. 6. Europe - Intellectual life. I. Title.

PN56.S46B73 $2018 \quad$ 809'.93353 C2018-901853-4

University of Toronto Press acknowledges the financial assistance to its publishing program of the Canada Council for the Arts and the Ontario Arts Council, an agency of the Government of Ontario.

Canada Council for the Arts

Funded by the Financé par le Government gouvernement of Canada
Conseil des Arts du Canada

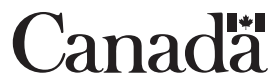

ONTARIO ARTS COUNCIL CONSEIL DES ARTS DE L'ONTARIO

an Ontario government agency un organisme du gouvernement de I'Ontario

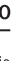


For Dan. 
This page intentionally left blank 